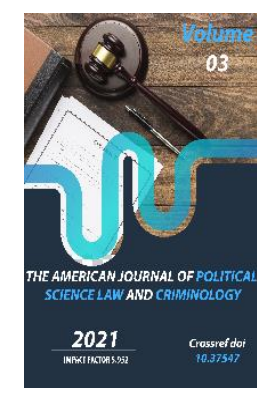

\title{
Modern Investment Legislation And Judicial Practice Are The Legal Guarantee Of Effective Reforms
}

\author{
Zaynobiddinova Farangiz Baxtiyor Qizi \\ PhD Candidate, University Of World Economy And Diplomacy, Uzbekistan
}

Journal Website:

https://theamericanjou

rnals.com/index.php/ta

jpslc

Copyright: Original content from this work may be used under the terms of the creative commons attributes 4.0 licence.

\section{ABSTRACT}

In this article, modern investment legislation is considered on the basis of legal acts regulating investment activity. The state of the investment climate in the country is summarized with judicial practice. In addition, in the scientific work has been analyzed the features and differences of the previous legislation of the Law of the Republic of Uzbekistan "On Investments and Investment Activities".

Furthermore, based on the results of the study, several proposals were recommended to improve legislation and practice of the Investment Activities in the Republic of Uzbekistan, the implementation of legal norms and to ensure effective protection of investors' rights.

\section{KEYWORDS}

Economic Growth, Investment, Investment Agreement, Investment Visa, Investment Subsidy, Integration Of States, Mediation.

\section{INTRODUCTION}

Today's globalization and the processes of integration of states into the global economy directly depend on the factors of attracting investment into the country's economy and creating a favorable investment climate for investors. To this end, it is necessary to ensure the stability of investment processes - the improvement of legal norms and mechanisms for regulating investment relations on the part of states.

In the world, as a result of the COVID-19 pandemic, there has been a sharp decline in 
global flows of foreign direct investment. According to the analysis [1], these resources, which are important for the economy of the countries, recorded a sharp drop of $\$ 1.5$ trillion compared to the level of 2019. This, in turn, is a serious blow to developing countries, especially in this situation, which negatively affects the production of export-oriented products and the implementation of investment projects in important sectors of the economy.

The issues of maintaining an effective investment policy in our country, increasing the share of private and direct investments in the economy, reducing external borrowing on behalf of the state, attracting more private capital to investment and infrastructure projects are recognized as an important area of state policy. In addition, special attention is paid to economic growth in our country, first of all, the creation of competitive production chains and the achievement of such projects through increased investment [2].

It is worth noting that the development of investment relations directly connects them with the issues of contractual and legal regulation. Because the contract is the most common form of attracting investment. Therefore, an in-depth scientific analysis of the issues of contractual regulation of investment relations plays an important role in alleviating the negative consequences of the pandemic, ensuring the legitimate interests and rights of investors, attracting investment in large sectors of the economy and small businesses. Because even in our country, at the beginning of the COVID-19 pandemic, there was a decline in economic activity, a decrease in domestic and external demand. The main factor in the slowdown in economic growth was the decline in investment and consumer activity due to the termination of the activities of a number of sectors of the economy. In Uzbekistan, there is a need to take important and effective shortterm measures in connection with this situation. In this regard, in order to prevent the threats of coronavirus against our country, the President and the Cabinet of Ministers have issued special regulatory documents.

\section{METHODS}

In science, several scientific studies have been conducted on the issues of contractual and legal regulation of investment activity, but most of them paid more attention to investment policy and economic aspects of investment activity. Some issues of investment law, contractual and legal regulation of investment activity were considered in the scientific works of scientists of our country B. Samarkhodjaev, O. Akyulov, S. Gulyamov, N. Imamav, I. Rustambekov,

B. Ochilov.

In particular, in the scientific works of B.Samarkhodaev [3], the concept, essence and principles of investment law, investment and legal relations, the concept and features of an investment contract are widely analyzed. O. Okyulov [4, P.236] analyzed in detail the assessment, examination and monitoring of investment funds and their legal status, as well as investment projects. N. Imomov [5, P.323] studied the essence of investment contracts, the concept of concession agreements and product distribution agreements in his research. S.Gulyamov [6] investigated the issues of international and national law, the problems of legal regulation of foreign investment. I. Rustamekov [7] studied important aspects of the formation of a favorable business and investment climate in 
our country, the importance of International commercial arbitration in the settlement of investment disputes under investment contracts, as well as issues related to the consideration of cases by the International Center for the Settlement of Investment Disputes. B.Ochilov [8] analyzed in detail the legal acts regulating investment activity in the Republic of Uzbekistan, issues of improving legislation in this area, as well as contractual and legal forms of attracting investment in the mining sector of the economy.

Within the framework of the CIS, this topic was discussed by I. Lunts,

N. Voznesenskaya, V. Lisitsa, A. Mingazova, Yu. Potapova, I. Vdovin, A. Bogatyrev, D. Ratnikova, B. Muravyev, I.Sevolnikova, O.Segelnik, A. Bogatyrev, I. Andreyanova, A.Shevchenko. In particular, in the scientific works of I. Sevolnikova [9], A. Shevchenko [10] and $A$. Mingazova [11] the issues of the system of civil law contracts regulating investment activities, their features and elements are studied in detail.

Specific problems of contractual regulation of investment activity in foreign countries in Europe: L. Constanta, L. Kotula, S. Christoph, G. Andrew and in the USA: R. Dolzer, T. Alli, K. Toni, K. Peinhardt, M. Sornaraja, A. Blaine Research. In particular, the scientific works of C. Richard [12], R. Dolzer [13], T. Alli, K. Peinhardt [14], Lorenzo Kotula [15] studied the methods and principles of legal regulation of investment activity and the issues of concluding bilateral investment agreements.

Despite the fact that many aspects of the legal regulation of investment activity are covered in the legal literature, there is not a single independent research work devoted to the disclosure of the features of the contractual and legal regulation of this activity, the essence of investment contracts. Also, the study did not attach sufficient importance to the issues of elements of civil law contracts regulating investment activities. This situation indicates that the sphere of contractual and legal regulation of investment activity has not been sufficiently studied.

\section{RESULTS}

In recent years, there have been many reforms in the field of investment activities. The legislative norms in this area have been revised, the normative legal documents have been improved. For instance, consistent measures are also being taken to radically improve and reform the investment policy, introduce modern effective approaches and mechanisms for its implementation, accelerate the investment process and improve the business environment as a whole. In particular, ensuring the implementation of the Action Strategy for the five priority areas of development of the Republic of Uzbekistan for 2017-2021 [16], in addition, in order to enforce the tasks set by the President of the Republic of Uzbekistan in his appeals to the Oliy Majlis of the Republic of Uzbekistan on January 25 and December 29, 2020 [17], "The year of active investment and social development", "The year of development of science, education and the digital economy", as well as "the year of youth support and public health promotion"- many tasks were set to ensure macroeconomic stability, create the necessary conditions for healthy competition, radically improve the business and investment climate, seriously reduce the state's participation in the economy, increase the return on investment, 
accelerate the attraction of investment in all sectors of the economy.

Furthermore, in order to continue an active investment policy, actively attract investment, including foreign direct investment, for the implementation of strategic and important investment projects for the technical and technological re-equipment of existing production and the organization of new hightech production, taking into account the measures taken to ensure the effective development and rational use of available resources, as well as, in order to ensure their level and quality of life, targeted programs were developed within the framework of the decree of the President of the Republic of Uzbekistan "On measures to radically improve the investment climate in the Republic of Uzbekistan" [18] dated August 1, 2018, “On measures to implement the investment program of the Republic of Uzbekistan for 2019" [19] and "On measures to implement the investment program of the Republic of Uzbekistan for 2020-2021" [20].

In addition, on December 25, 2019, the main, special document was adopted aimed at regulating investment activities in our country - the Law of the Republic of Uzbekistan "On Investments and Investment Activities" [21] (hereinafter referred to as the Law).

This law is aimed at regulating relations in the field of investments and investment activities carried out by foreign and local investors, and is the only document combining the main provisions of the laws of the Republic of Uzbekistan "On investment Activity", "On guarantees of the rights of foreign investors and measures to protect them" and "On foreign investment". This law is also notable for the fact that investment relations are regulated by more specific norms, guarantees of investors' rights are increased and additional requirements are established regarding the content of investment contracts [22, P.97]. We can also note the following differences and features of the law from previous regulatory legal acts:

The legal status of local and foreign investors was established, in particular, the concept of local investors was strengthened; additional rights were granted to foreign investors. This, according to the expert B. Legum, is also an important situation, thanks to which the main subjects of investment activity and their rights are additionally explained [23].

$\checkmark$ Foreign investors have the right to obtain a residence permit and an "investment visa", including on the conditions stipulated by the decisions of the President of the Republic of Uzbekistan, in accordance with the terms of the validity of the" investment visa", their family members can also have the right to reside. Also, the conditions for foreign investment cannot be more unfavorable and the state guarantees a stable investment climate, equal and fair conditions for all investors.

$\checkmark$ The procedure for concluding an investment agreement with the Government of the Republic of Uzbekistan and terminating the contract, the terms of the contract and the parties, the initiative to make proposals for concluding this type of contract and the norms on the obligations of a foreign state, as well as an additional requirement were noted.

$\checkmark$ State support measures have been established and are currently in accordance with them: a) Investors can be provided 
with an investment tax credit, investment subsidies; b) state bodies, diplomatic missions abroad and consular offices assist investors in obtaining advice and information; C) representative for the protection of the rights and legitimate interests of business entities under the President of the Republic of Uzbekistan.

$\checkmark$ The legal framework of enterprises with the participation of foreign investments has been established, according to which: the amount of foreign investment in enterprises is at least fifteen percent (this requirement is provided for the first time in an act of the law); property imported by these enterprises for their own needs is exempt from customs duty for two years.

$\checkmark$ A new stage of the dispute resolution mechanism, strengthened by multilateral investments. New in accordance with this, a dispute (investment dispute) arising in connection with foreign investments and during the implementation of investment activities of a foreign investor on the territory of the Republic of Uzbekistan can be resolved through the following stages:

\section{$\square$ I - negotiations;}

$\square$ II - mediation;

$\square$ III - the relevant court of the Republic of Uzbekistan;

IV - International Arbitration.

The issues of ensuring guarantees of investment protection and the rights of investment entities established by the state are regulated separately, according to which: the right of state bodies and their officials to interfere in activities carried out in accordance with the investment law; investments and other assets of investors are not nationalized; as well as the right of state bodies and their officials to interfere in activities carried out in accordance with the investment law.; It was noted that if subsequent legislation worsens the conditions for investment, the legislation in force on the date of investment should be applied to investors within ten years from the date of investment.

In addition to analyzing the current investment legislation in our country, we can study the practice of investment activity, in particular, important aspects of concluding and implementing investment contracts through judicial practice in this area.

In particular, within the framework of the topic, more than 40 court cases were studied [24], which were considered by the economic courts of the Republic of Uzbekistan in connection with investment contracts in 01.2018 - 05.2021, and proposals were developed to improve the contractual and legal regulation of the acquisition of investment disputes.

In particular, the buyer's failure to fulfill investment obligations under a purchase and sale agreement concluded on the condition that investment obligations are included in judicial practice is considered a serious violation of the contract, and this situation becomes the basis for termination of the contract [25, P.306].

A similar situation took place in the case considered by the Chust Interdistrict Economic Court (05.04.2021) No. 4-1603-2102/354. He did not provide monthly information and quarterly reports on its execution. That is, the fulfillment of investment obligations in investment contracts is not enough, the obligations must 
be confirmed by the corresponding tabular reports.

In the case of the Tashkent Interdistrict Economic Court (March 16, 2020) No. 4-1001$2001 / 3971$ on early termination of the lease agreement No. 5956 / 10-18 for the lease of state property located in a small industrial zone on the street. condition for accepting the declared investment obligations. According to the monitoring of the fulfillment of investment obligations by the "asset holder", the "lessee" did not submit a report on the fulfillment of investment obligations, although he was obliged to create 5 new jobs, but in practice no jobs were created. , as well as operation. The absence of a contract for the provision of services has been established. The plaintiffs' representatives also stated that the dispute was not registered by the state in the manner prescribed by the treaty.

In case No. 4-1001-2016 / 17717, considered by the Judicial Collegium on Economic Issues of the Supreme Court of the Republic of Uzbekistan in cassation (04.16.2021), the Chamber of Commerce and Industry of Uzbekistan filed a statement of claim. The statement of claim and asked the defendant to recover in favor of the plaintiff 1,062,016,992 soums of investment costs and 30,873,334 soums of damages.

In turn, in case of termination of the contract on the initiative of the defendant in clause 10.5, all investment costs are returned to the investor at market value (at the market value of the object) within 30 banking days after receiving a request from the investor. decided to give it up. In this case, given that the contract between the parties was terminated by a court decision on the initiative of the defendant, the terms of the contract provide for reimbursement of costs at market value, the defendant did not dispute the appraisal report. That is, the courts came to a wellgrounded conclusion on the recovery of 1,062,016,992 sum.

In case No. 4-1105-2101/84, considered by the Judicial Collegium on Economic Issues of the Tashkent Regional Court in the Court of Appeal (05/04/2021), although the interim periods are indicated in the investment schedule under the contract. The court of first instance, without taking into account the above circumstances and without demanding the necessary documents from the plaintiff, imposed a fine on the plaintiff LLC-defendant in the amount of $120,000,000$ sum for non-compliance with the pre-trial procedure. Settlement of a dispute (application). It was noted that the refusal to satisfy the claim for termination of the sale and purchase agreement No. 370/19-BS was unreasonable and premature, and the claim was satisfied. This fact testifies to the legitimacy of applying to the courts of the next instance to protect the interests of the plaintiffs, recognizing the procedural shortcomings admitted by the courts of first instance when considering investment disputes.

We may also find that in some investment dispute lawsuits, the plaintiff has partially or completely retracted his promise in court. The defendant, who did not fulfill his obligations under the investment agreement on time, in many cases began to fulfill the terms of the agreement, having received a summons. Thus, in our opinion, the inclusion in investment agreements of a clause that the parties can resolve disputes through mediation - in many 
cases of conflict - may provide an opportunity to resolve problems in the pre-trial process.

\section{CONCLUSION}

Despite legislation and sustained reforms, each region of the country, there are still certain problems in investment activity, the solution of which will further increase the importance of research in this area. In particular, according to some foreign experts, the main obstacles to the development of this sector in Uzbekistan are: diversification of the economy and dependence on commodity prices; low competitiveness; underdeveloped banking sector and other factors.

It is worth noting that, in addition to the introduction of modern investment legislation into practice, the development of modern tools for regulating investment activities currently has a direct impact, in particular, on reducing corruption risks, improving tools in the form of possessive norms; establishing investment regimes that stimulate insignificant capital investments aimed at innovative development; there was a need to implement such reforms as the formation of a favorable environment conducive to the growth of local investment, as well as the introduction of a form of mass fraud before the legislative body of the executive power for the implementation of laws aimed at stimulating investment. The search for a correct and complete solution to these issues plays an important role in the modern development of the country's economy.

In addition, with the analysis of the existing judicial practice, in particular, on 40 court cases considered by the economic courts of the Republic of Uzbekistan in connection with investment agreements in 01.2018-05.2021, the following conclusions and recommendations can be made:

- Most investment disputes arise due to the fact that the parties do not fulfill their obligations under the contract. In this regard, it is advisable when signing an investment agreement, the parties set specific deadlines for each condition and legal consequences for the party that has not fulfilled its obligation during this time or has not fulfilled its obligation to the necessary extent in accordance with the purpose;

- Due to the large number of cases of settlement of disputes under an investment agreement from the moment of going to court to the appointment of a meeting, taking into account the partial or complete refusal of the plaintiffs from the claim, the inclusion of a mediation clause in contracts may allow disputes to be resolved quickly in the pre-trial process.

- In most cases considered by the economic courts of the Republic of Uzbekistan, the claim arose in connection with the delay in the fulfillment of the defendant's obligations. In particular, due to the announced quarantine measures to combat the pandemic that has affected the whole world, and its negative losses, many investors were unable to invest their investment capital in a timely manner in accordance with the agreed contract. In this regard, the need to make changes to the timing of the implementation of individual investment projects is justified, to develop a bill to mitigate liability for violation of the terms of investment agreements in a difficult epidemiological situation, for the legal protection of 
investors and to include such clauses in future investment agreements.

In fact, we can cite many more specific aspects of modern investment legislation and practice. However, the most important thing is to further improve the business environment in our country by effectively implementing these standards in practice, increasing the volume of foreign investment and increasing investment attractiveness. That is why the President of the Republic of Uzbekistan Sh. Mirziyoyev emphasized that, " World experience shows that the state, which pursued an active investment policy, achieved stable growth of its economy. Therefore, investment is the driver of the economy, in Uzbek terms, the heart of the economy, if I say so, it will not be an exaggeration. Along with investments, new technologies, advanced experience, highly qualified specialists will enter various spheres and industries, regions, entrepreneurship will develop rapidly"[26].

\section{REFERENCES}

1. World Investment Report 2020. International Production beyond the Pandemic. UNCTAD. UN Geneva, 2020 II

URL: https://unctad.org/system/files/officialdocument/wir2020_en.pdf

2. President Shavkat Mirziyoyev's Address to the Oliy Majlis, 29.12.2020 // URL:

https://president.uz/uz/lists/view/4057

3. Samarhodjaev B.B. Investment law Textbook for universities. - T.: UWED, 2014; Samarkhodzhaev B.B. Investments in the Republic of Uzbekistan. - T.: Academy, 2003.
4. Organizational and legal forms of investment activity: Textbook. A team of authors. -T.: TDYUU, 2018.

5. O.Okyulov, N.Imomov, Sh.Ruzinazarov, B.Samarkhodjaev, I.Rustambekov, Q.Mehmonov, E.Musaev, U.Saydaxmetov, A.Tojiboev, A.Ibragimova, A.Jumagulov. Investment law. Textbook. TSUL, 2019.

6. Gulyamov S.S. Legal regulation of foreign investments in the Republic of Uzbekistan. dis. ... Cand. legal entity Sciences .: spec. 12.00.03 / Tashkent 2002.

7. Rustambekov I. Business Environment and Investment Climate in the Republic of Uzbekistan. // International Journal of Advanced Research. \#4, 2019. P. 1282- 1285. DOI: 10.21474/ijaro1/8951; Rustambekov I.R. International commercial arbitration. Textbook. - T .: TSUU, 2018.

8. Ochilov B.E. Implementation of effective contractual forms of attracting investment in the extractive industries of the economy of the Republic of Uzbekistan // Lawyer herald - T .: 2020. Volume 1. No.1 // URL: https://www.yuristjournal.uz/index.ph p/lawyer-herald/article/view/36/10 Ochilov. B.E. Improvement of the investment legislation of the Republic of Uzbekistan by adopting a unified act in the field of investments and investment activity // Republican scientific and practical conference "Improving the legal mechanisms for attracting foreign investment in the economy of the Republic of Uzbekistan" - T .: UWED, 2019. 
9. Tsevolnikova I.Yu .., Civil law regulation of investment activity: author. dis. for a job. learned. step, candidate of legal sciences: special 12.00.03 / - M :: RSL, 2005. I/ URL: http://lawtheses.com/grazhdanskopravovoe-regulirovanieinvestitsionnoy-deyatelnosti

10. Shevchenko AP, Investment contracts with a foreign investor in the law of the Republic of Belarus: dis. Minsk, 2012.

11. Mingazova A.M., Contractual regulation of investment activity: author. dis. for a job. learned. step, candidate of legal sciences: special 12.00.03 / Kazan 2017. |/ URL: https://www.twirpx.com/file/2162327/

12. Ch.Richard. Bilateral Investment Treaties and Domestic Institutional Reform, Columbia Journal Of Transnational Law, 2017/ 55: 548-591 // // URL: http://jtl.columbia.edu/wpcontent/uploads/sites/4/2017/08/Chen_ 55_CJTL_547.pdf

13. Dolzer, Rudolf and Christoph Schreuer. 2012. Principles of International Investment Law. New York, NY: Oxford University Press // URL: https://opil.ouplaw.com/view/10.1093/l aw/9780199651795.001.0001/law9780199651795 ., Dolzer Rudolf "Indirect Expropriations: New Developments?” (2002) 11 N Y U Envtl LJ 64 . // URL: https://heinonline.org/HOL/LandingPa ge?handle=hein.journals/nyuev11\&div= $11 \&$ id=\&page $=$

14. Allee, Todd \& Clint Peinhardt (2014). Evaluating Three Explanations for the Design of Bilateral Investment Treaties, World Politics, Vol. 66 // URL:
https://doi.org/10.1017/S004388711300

0324

15. Lorenzo Cotula. Investment Contracts and Sustainable Development. International Institute for Environment and Development (2010) // URL: https://pubs.iied.org/sites/default/files/ pdfs/migrate/ 17507lIED.pdf

16. National legislative base, 07.06.2018 y., 06/18/5456/1316

17. President Shavkat Mirziyoyev's Address to the Oliy Majlis, 25.01.2020 // URL:

https://president.uz/uz/lists/view/3324; President Shavkat Mirziyoyev's Address to the Oliy Majlis, 29.12.2020 // URL:

https://president.uz/uz/lists/view/4057

18. National legislative base, 02.08.2018 y., 06/18/5495/1611

19. National legislative base, 20.12.2018 y., 07/18/4067/2354

20. National legislative base, 18.08.2020 y., 06/20/6042/1190

21. National legislative base, 26.12.2019 й., 03/19/598/4221

22. Zaynobiddinova. F.B. Legal aspects of active investment policy. Materials of the 15th Republican Multidisciplinary Scientific Distance Online Conference on Scientific and Practical Research in Uzbekistan. April 30, 2020. // URL: https://tadqiqot.uz/wpcontent/uploads/2020/05/Aprel_conf_ 2020/Aprel_conf_2020_part_1.pdf

23. Legum. B. "Defining Investment and Investor: Who is Entitled to Claim?" presentation at the Symposium "Making the Most of International Investment Agreements: A Common 
Agenda" co-organised by ICSID, OECD and UNCTAD, 12 December 2005, Paris.

24. Supreme Court of the Republic of Uzbekistan. Posting on the Internet of court documents on cases considered in the economic courts of the Republic of Uzbekistan // URL: https://public.sud.uz/\#!/sign/economy

25. 25. Judicial practice in economic cases. Practical guide / A. Abdullaev. Tashkent publishing house of complex printing, 2018. // URL: https://sud.uz/wpcontent/uploads/2019/07/obzoriqtisodi $y \cdot p d f$

26. UZBEKISTAN: FOREIGN INVESTMENT. Export Entreprises SA, May 2020. // URL:https://santandertrade.com/en/po rtal/establishoverseas/uzbekistan/investing? \&actualiser_id _banque =oui\&id_banque $=0 \&$ memoriser_choix $=$ memoriser 